sexuality, and security in global politics, with foci on feminist security theorizing and women's violence in global politics. She is the author or editor of twelve books, including, most recently, Women as Wartime Rapists (2016) and (with J. Samuel Barkin) Interpretive Quantification (2017). Her work has been published in more than two dozen journals in political science, international relations, gender studies, law, and geography, including International Studies Quarterly, Feminist Review, and Political Geography. She currently serves as Homebase Editor of the International Feminist Journal of Politics and coeditor of International Studies Review. She teaches undergraduate and graduate courses in methodology, international security, international law, and gender in global politics.

Sjoberg served as program chair of the Sexuality and Politics Organized Section from 2012 to 2013 and section chair from 2013 to 2014. She served as the co-program chair of the Women and Politics Organized Section from 2013 to 2014, and secretary of the section from 2010 to 2012. She participates in the APSA mentoring program, and served on the Committee to Rename the International Relations Dissertation Award from 2015 to 2016. In addition to her work at APSA, she has been active in the International Studies Association (where she served as vice president from 2015 to 2016), the Southern Political Science Association, the International Studies Association-Northeast, and the International Studies Association-West. She has served on the editorial boards of International Studies Quarterly, International Studies Perspectives, Review of International Studies, Foreign Policy Analysis, Critical Studies on Terrorism, and the Journal of Global Security Studies.

Statement of Views: I appreciate the honor of nomination to the APSA Council. I have been a member of and benefitted from
APSA for my entire career, and I look forward to having the opportunity to give back. It is important to me that APSA serves its diverse membership. This means, to me, paying attention to how APSA serves its minority members, how it serves its members from a wide variety of institutions, and how it serves its members of a wide variety of scholarly interests. Only through valuing representational and substantive diversity in our governance and in our programming will APSA enrich both teaching and research. I look forward to working to push APSA even further as it develops programming to promote diversification.

\section{Carol Weissert}

Carol Weissert (nominated for one-year term) is LeRoy Collins Eminent Scholar and Professor of Political Science at Florida State University (FSU). In 2016 she was

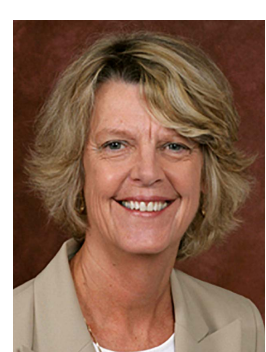
Fulbright Distinguished Professor in American Political Science at Flinders University in Adelaide, Australia.

Her principal research interests are federalism and state politics with a special focus on health policy. She is the former editor of Publius: The Journal of Federalism. Her current research explores intergovernmental bargaining between federal and state governments, vertical diffusion of policies, policy implementation, and the impact of devolution.

She is coauthor of Governing Health: The Politics of Health Policy (now in its fourth edition); her research has appeared in journals including the Journal of Politics, Publius: The Journal of Federalism, Journal of Health Politics, Policy and Law, Legislative Studies Quarterly, Journal of Public Administration
Research, and Theory, Health Affairs, Political Research Quarterly, and Administration and Society.

She is the recipient of the Daniel Elazar Award for Distinguished Scholarship in Federalism and Intergovernmental Relations from the Federalism Organized Section of APSA and the Donald Stone Award for Distinguished Scholarship in Intergovernmental Relations from the Organized Section on Intergovernmental Relations of the American Society of Public Administration. She is a fellow of the National Academy of Public Administration.

She has been president of the Southern Political Science Association and has chaired the Federalism Organized Section of APSA. In addition, she has held leadership positions in and chaired committees for State Politics and Policy, Public Policy, and Health Politics and Policy Organized Sections of APSA. She was chair of APSA's Organized Section Committee.

She has served on editorial boards of the American Political Science Review, State Politics and Policy Quarterly, Publius: The Journal of Federalism, and the Journal of Political Science Education. At FSU she is director of the LeRoy Collins Institute for Public Policy. Prior to coming to FSU, she was professor of political science and director of the Institute for Public Policy and Social Research at Michigan State University. Her PhD in political science is from the University of North Carolina, Chapel Hill.

Statement of Views: On the Council, I will encourage cooperation and close working relationships with organized sections which comprise a key component of the success of APSA. I will work to strengthen APSA's efforts to welcome and mentor new members, especially graduate students and junior scholars, and to foster new mechanisms for member feedback on APSA's member services and support.

\title{
Continuing Council Members
}

\section{PRESIDENT}

\section{Kathleen Thelen}

Kathleen Thelen is Ford Professor of Political Science at MIT. She received her BA from the University of Kansas and her PhD from the University of California, Berkeley. Thelen is a comparativist whose work focuses on the origins and evolution of political-economic institutions in the rich democracies. Her latest book, Varieties of Liberalization and the New Politics of Social Solidarity (2014), received the Barrington Moore Prize and was cowinner of Best Book

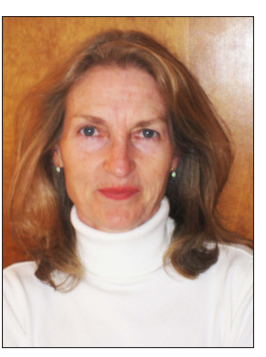

in the European Politics and Society Section. A previous work, How Institutions Evolve, was selected for the 2006 Mattei Dogan Award, and shared the 2005 Woodrow Wilson Foundation Award. Thelen has also contributed to the literature on institutional analysis, including Advances in Comparative Historical Analysis (2015) and Explaining InstitutionalChange (2010), both 
coedited with James Mahoney, Beyond Continuity (2005, with Wolfgang Streeck) and Structuring Politics (1992, with Sven Steinmo). Her article "Historical Institutionalism in Comparative Politics" remains the most cited and most downloaded contribution to the Annual Review of Political Science. Her work has also appeared in a number of journals, including World Politics, Comparative Political Studies, and Politics \& Society, among others.

Thelen has been awarded fellowships from the Institute for Advanced Study (Berlin), Radcliffe Institute, Oxford University, the Max-Planck-Society, and the AmericanScandinavian Foundation, among others. She is a Permanent External Scientific Member of the Max Planck Institute for the Study of Societies, and has held visiting appointments in Europe (Sweden, UK, France, Denmark) and Latin America (Mexico, Argentina). She was chair of the Council for European Studies (2002-2006) and President of the Society for the Advancement of Socio-Economics (2008-2009). Along with Erik Wibbels, she edits the Cambridge University Press Series in Comparative Politics. She is a member of the American Academy of Arts and Sciences (since 2015) and its German equivalent, the Berlin-Brandenburg Academy of Sciences (since 2009).

Thelen has been active in the association, most recently as a member of APSA Council and Treasurer. She has also served on numerous committees and as an officer in several Organized Sections-Comparative Politics (president), Politics and History (president), Qualitative and Multi-Method Research (vice-president), and European Politics and Society (treasurer).

\section{Matt A. Barreto}

Matt A. Barreto is cofounder and managing partner of the polling and research firm Latino Decisions which he cofounded with Gary Segura in 2007. Barreto is also profes-

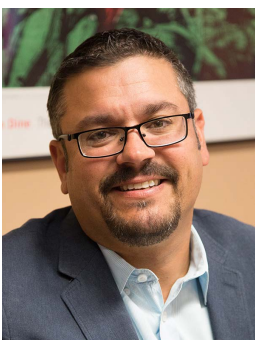
sor of political science and Chicana/o studies at University of California, Los Angeles (UCLA). In 2012 Time Magazine called Latino Decisions the "goldstandard in Latino American polling," and Barreto's research was recognized in the 30 Latinos who made the 2012 election by Politic365. He was listed in the Top 100 Global Thinkers of 2012 by the European
Politics Magazine LDSP and was named one of the top 15 leading Latino pundits by Huffington Post, which said Barreto was "the pollster that has his finger on the pulse of the Latino electorate." In 2015, Barreto was hired by the Hillary Clinton presidential campaign to run polling and focus groups on Latino voters.

In 2010 Barreto implemented the first ever weekly tracking poll of Latino voters during the 2010 election, which Latino Decisions continued in 2012. Working closely with Segura, he has also overseen large multistate election eve polls, battleground tracking polls, extensive message testing research, and countless focus groups. He has been invited to brief the US Senate, the White House, and Congressional Committees, and has been a keynote speaker at many of the major Hispanic association conferences including NALEO, LULAC, CHCI, NCLR, and others.

He received his $\mathrm{PhD}$ in political science from the University of California, Irvine. Barreto has published more than 40 scholarly research articles and book chapters that examine Latino public opinion, voting behavior, and race politics more generally in America. He is also the author of the two books, Ethnic Cues: The Role of Shared Ethnicity in Latino Political Behavior (University of Michigan Press, 2010) as well as Change They Can't Believe In: The Tea Party and Reactionary Politics in America (Princeton University Press, 2013). He just completed his third book, Latino America, coauthored with Segura, on the growth and influence of Latino voters 2008-2012 presidential elections (Public Affairs Press)

In 2008, Barreto was a co-principal investigator (with Gary Segura) of the American National Election Study Latino oversample, which included the first ever Spanish language translation of the ANES and the first ever oversample of Latino voters. In 2009, he was appointed to the ANES Board of Overseers.

\section{Christina Wolbrecht}

Christina Wolbrecht is associate professor of political science and director of the Rooney Center for the Study of American Democracy at the University of Notre Dame. She received her PhD from Washington University in St. Louis.

Wolbrecht's areas of expertise include American politics, political parties, gender and politics, and American political development. She is the coauthor, with J. Kevin Corder, of Counting Women's Ballots: Female Voters from Suffrage through the New Deal (Cambridge 2016), a project supported by the National Science Foundation. She also is the author of The Politics of Women's Rights: Parties, Positions, and Change (Princeton 20oo), which received the 2001 Leon D. Epstein Outstanding Book Award from the Political Organizations and Parties Organized Section of APSA. Wolbrecht's work on party position-taking, women as political role models, the representation of women, and support for political institutions has appeared in journals including Perspectives on Politics, American Journal of Political Science, Journal of Politics, and Legislative Studies Quarterly. She has coedited books on the American political parties, women as political actors, and democratic inclusion.

Wolbrecht is a coeditor of Cambridge Studies in Gender and Politics for Cambridge University Press, and serves or has served on the editorial boards of the American Journal of Political Science, Journal of Politics, Legislative Studies Quarterly, and Politics \& Gender. She has been active in the discipline, chairing or serving on a number of APSA MPSA, and SPSA committees and caucuses. Wolbrecht is an editorial board member of the \#WomenAlsoKnowStuff initiative.

\section{Colleen Shogan}

Colleen J. Shogan is the deputy director of National and International Outreach at the Library of Congress and an adjunct assistant professor of government at George-

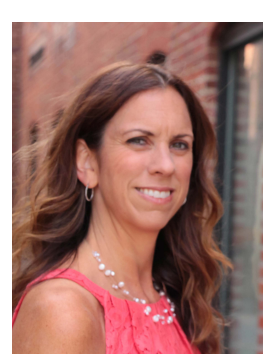
town University. At the Library, she supervises programs such as the Center for the Book, National Library Services for the Blind and Physically Handicapped, the National Book Festival, the Publishing Office, the Federal Research Division, the Kluge Center for Scholars, exhibits, visitor services, and K-12 Educational Outreach.

She holds a PhD from Yale University in political science and a BA from Boston College. At Yale, she was a National Science Foundation graduate fellow. Her intellectual interests include American political development, the presidency, Congress, and political rhetoric. Her recent research has focused on congressional social media usage. 
At Georgetown, she teaches a graduate seminar on APD.

She previously served as the deputy director at the Congressional Research Service (CRS) and as a Senate policy staffer. She came to Capitol Hill through the Congressional Fellowship Program as the William E. Steiger Fellow. In the 112th Congress, Colleen participated in the Stennis Fellows Program

Before working in Congress, Colleen was an assistant professor at George Mason University. Her first book, entitled The Moral Rhetoric of American Presidents, was published by Texas A\&M University Press. She has also published articles in Perspectives on Politics, Polity, PS: Political Science \& Politics, Studies in American Political Development, Presidential Studies Quarterly, Rhetoric \& Public Affairs, Women \& Politics, White House Studies, Online Information Review, and Social Movement Studies.

Colleen is a past president of the National Capitol Area Political Science Association and serves on the board of directors for the Presidency and Executive Politics research group and the advisory panel for the Beryl Radin Pracademic Fellowship. She is a member in good standing of the Cosmos Club. Colleen is also a mystery writer and has published two novels set on Capitol Hill with Camel Press.

\section{Juliet Hooker}

Juliet Hooker is associate professor of government and of African and African Diaspora studies at the University of Texas, Austin. She is a political theorist whose pri-

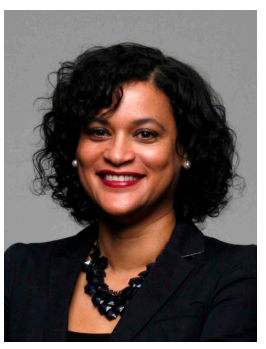
mary research interests include comparative political theory and critical race theory, particularly black political thought, Latin American political thought, political solidarity, and multiculturalism; she has also published on Afro-descendant and indigenous politics and multicultural rights in Latin America. Hooker is the author of Race and the Politics of Solidarity (Oxford University Press, 2009), and has a forthcoming book Theorizing Race in the Americas: An Intellectual Genealogy (Oxford, 2016) that juxtaposes four prominent US African-American and Latin American thinkers: Douglass, Sarmiento, Du Bois, and Vasconcelos. Her work has been supported by the National Endowment for the Humanities, and has appeared in such journals as the American
Political Science Review, Political Theory, Politics, Groups and Identities, Souls, Journal of Latin American Studies, and Latin American Research Review. Hooker recently served as cochair of the APSA Presidential Task Force on Racial and Social Class Inequalities in the Americas (2014-2015), and as associate director of the Teresa Lozano Long Institute of Latin American Studies at UT-Austin from 2009 to 2014. She is an editorial board member of the National Political Science Review journal of the National Conference of Black Political Scientists. Within APSA she has served on the Okin-Young Award and First Book Award Committees of the Foundations of Political Theory Organized Section. Hooker is an award-winning teacher, and has held visiting fellowships at the CUNY Graduate Center, the Du Bois Institute for African American Research at Harvard University, and the Kellogg Institute for International Studies at Notre Dame.

\section{Kristian Skrede Gleditsch}

Kristian Skrede Gleditsch is professor, department of government, University of Essex and research associate, Peace Research Institute Oslo. He has a PhD

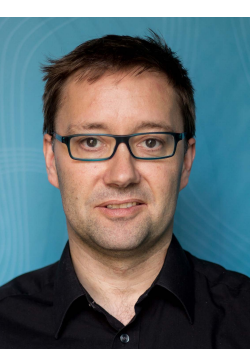

in political science from the University of Colorado. His research interest includes conflict and cooperation, democratization, political geography, political methodology, and data development.

He is the author of Inequality, Grievances, and Civil War (Cambridge University Press, 2013, with Lars-Erik Cederman and Halvard Buhaug), Spatial Regression Models (Sage 2008, with Michael D. Ward), All International Political is Local: The Diffusion of Conflict, Integration, and Democratization (University of Michigan Press, 2002), and articles in numerous journals including the American Journal of Political Science, American Political Science Review, International Organization, International Studies Quarterly, Journal of Conflict Resolution, Journal of Peace Research, Journal of Politics, Political Analysis, and World Politics.

His research has received several awards, including the 2014 Conflict Processes Organized Section best book award, the 2012 Heinz I. Eulau best article award and the 2000 Helen Dwight Reid dissertation award from APSA, and the 2007 Karl Deutsch Award from the International Studies Association.
He has received grants from the Alexander von Humboldt Foundation, European Research Council, National Science Foundation, and the Research Council of Norway.

Gleditsch is head of the APSA Conflict Processes Organized Section 2014-2016 and chairs an APSA dissertation award committee for 2016. He has also been a vice president of the International Studies Association (2014-2015) and chaired its Committee on Professional Rights and Responsibilities (2014-2016). He has served as coeditor for Research and Politics (2015-2016) and the British Journal of Political Science (2010-2013) and is a member of several editorial boards.

\section{Mark Crescenzi}

Mark Crescenzi is a Bowman and Gordon Gray Term Professor of Political Science at the University of North Carolina, Chapel Hill (UNC). He received is BA from the

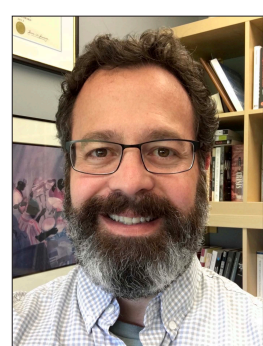
University of California, Irvine, and his MA and $\mathrm{PhD}$ from the University of Illinois, UrbanaChampaign. He has been teaching at UNC since 1999. His research centers on the study of peace and conflict processes, with a focus on the effects of reputation on conflict, cooperation, and coordination; the link between regime dynamics and violence within and between states; and the role of economics in interstate conflict. His research has appeared in journals such as the American Journal of Political Science, Conflict Management and Peace Science, International Studies Quarterly, International Theory, the Journal of Conflict Resolution, the Journal of Peace Research, and the Journal of Politics. He published a book with Lexington Press in 2005 on economic interdependence and international conflict, and his research has been supported by the National Science Foundation. He teaches undergraduate and graduate courses in international relations, the causes of conflict in world politics, and conflict management and resolution.

Crescenzi served as section president of the Conflict Processes Organized Section from 2010 to 2012, and has served on the section's council. In 2015-2016, he also served on the Committee to Rename the Helen Dwight Reid Award. In addition to his work with APSA, he has been active in the International Studies Association, Midwest Political Science Association, and Peace 
Science Society, and has served on the editorial boards of the American Journal of Political Science, International Studies Quarterly, and the Journal of Politics.

\section{Omar G. Encarnación}

Omar G. Encarnación is professor of political studies at Bard College, where he teaches comparative politics and Latin American and Iberian studies. His research focuses on

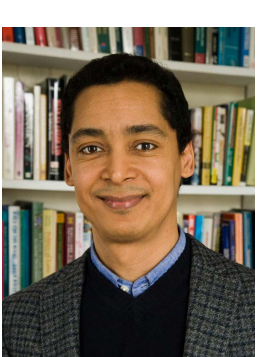
the causes and consequences of transitions to democracy, the role of civil society in the process of democratization, and the policy choices that new democracies make to cope with a difficult and painful past. He is the author of four books, including, Democracy without Justice in Spain: The Politics of Forgetting (University of Pennsylvania Press, 2014) and Out in the Periphery: Latin America's Gay Rights Revolution (Oxford University Press, 2016), and more than a dozen peer-reviewed articles and reviews published in Comparative Politics, Political Science Quarterly, Comparative Political Studies, International Studies Quarterly, Journal of Democracy, Mediterranean Quarterly, West European Politics, Acta Politica, Human Rights Quarterly, Perspectives on Politics, Ethics \& International Affairs, South European Society and Politics, and Studies in Comparative International Development. His political commentary appears in The New
York Times, Foreign Affairs, The Wilson Quarterly, Current History, Orbis, Global Dialogue, World Policy Journal, The Irish Times, and World Politics Review.

Encarnación received his $\mathrm{PhD}$ from the department of politics of Princeton University, and taught at Sarah Lawrence College prior to coming to Bard. While at Princeton, he was the recipient of numerous awards and fellowships, including Princeton University's Presidential Fellowship, the Council for European Studies Pre-dissertation Fellowship, and a Fulbright Dissertation Fellowship to Spain. Since completing the $\mathrm{PhD}$, he has been awarded a Ford Foundation Post-doctoral Fellowship and research grants from the Spanish Ministry of Culture and the National Research Council, and has been named a visiting fellow at the Center for Advanced Studies in the Social Sciences of the Juan March Institute in Madrid, Georgetown University's Center for Latin American Studies, the Carnegie Endowment for International Peace in Washington, DC, and the political science department of New York University. He has worked as a consultant for the US State Department, the World Bank, and Freedom House. Past service for APSA includes cofounding the Iberian politics group and serving as program chair for the comparative democratization section.

\section{Renée Bukovchik Van Vechten}

Renée Bukovchik Van Vechten is an associate professor of political science at the University of Redlands. She earned a BA in political science from the University of San

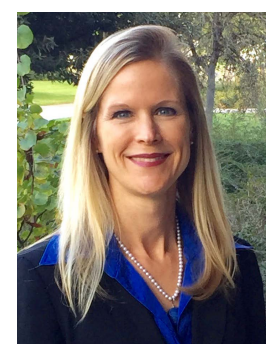

Diego and a $\mathrm{PhD}$ from the University of California, Irvine. Van Vechten's political science research examines legislative processes and behavior, including the impacts of political reforms such as term limits. Her work on state-level politics and policy is evident in her textbook, California Politics: A Primer, and she has a chapter in the APSA book, Teaching Civic Engagement: From Student to Active Citizen. Her scholarship on pedagogical practices has extended to research methods, online discussion forums, simulations, and internships. Van Vechten served as chair of the APSA Political Science Education Organized Section from 2013-2015. She was the section's program chair for the 2013 annual meeting, and has been a track moderator for the APSA Teaching and Learning Conference 2014-2016. Service to the association includes membership on awards committees and the Presidential Task Force on Technology (2015-2016), and helping to facilitate the transfer of sponsorship of the Journal of Political Science Education to APSA. Van Vechten is also active in the Western Political Science Association, having cochaired a conference-within-aconference on teaching and learning (2015, 2016). She has received several teaching awards, including the Rowman and Littlefield Award for Innovative Teaching in Political Science (via APSA) in 2008. 